\title{
The Impact of Multiple Intelligences-Based Instruction on Developing Speaking Skills of the Pre-Service Teachers of English
}

\author{
Ashraf Atta M. S. Salem ${ }^{1}$ \\ ${ }^{1} \mathrm{PhD}$ in TEFL, Institute of Educational Studies \& Researches, Cairo University, Egypt \\ Correspondence: Ashraf Atta M. S. Salem, State of Kuwait, Mahboula, Block 1, Street 131, Building 24, behind \\ Alhashel Complex. E-mail: sirashrafams@hotmail.com
}

Received: June 11, 2013 Accepted: July 2, 2013 Online Published: August 15, 2013

doi:10.5539/elt.v6n9p53 URL: http://dx.doi.org/10.5539/elt.v6n9p53

\begin{abstract}
The current study investigates the impact of multiple intelligences-based Instruction on developing speaking skills of the pre-service teachers of English. Therefore, the problem of the current study can be stated in the lack of speaking skills of the pre-service teachers of English in Hurgada faculty of Education, South Valley University. To confront this problem, the researcher developed a multiple-intelligences based program to enhance the speaking skills paying a due attention to the individual differences among students. The sample of the study consists of sixty fourth-year Prospective teachers of English. The Quasi-experimental research design was used in the study as the researcher used the one group pre-posttest to assess the usefulness of using this approach. Results of the study proved the effectiveness of Multiple-intelligences based Instruction on developing speaking skills of the pre-service teachers of English.
\end{abstract}

Keywords: of multiple intelligences-based instruction, speaking skills, pre-service teachers of English

\section{Introduction}

\subsection{Introducing the Problem}

The current study investigates the effectiveness of using a multiple intelligences based instruction on developing the speaking skills of English Majors. Therefore, the study is of ultimate importance because it deals with students teachers as they are to be teachers the next year to transfer these skills, if mastered, to their students.

The main hypothesis of the study is that there are statistically significant differences between the mean scores of the experimental group in Students' Performance in Speaking Skills and Subskills. The subskills included in the study are the oral presentation skills, making suggestions, making requests, and giving advice. In order to test these hypotheses, the researcher selected randomly a group of sixty students in Hurgada faculty of Education to be pretested and posttested to assess the effect of implementing the training programme.

The study represents a step towards developing English Majors' speaking skills. This desire arose from the importance of these skills for prospective teachers of English. Moreover, it should be of interest that the participants in this study are going to teach students to be proficient speakers afterwards.

\subsection{The Importance of the Study}

The current study is of special significance for the prospective teachers of English. The study adopts a new theory (MI Theory) in the field of English Language Teaching, which may result in many useful implications for teachers and researchers. MI Theory calls for multi-modal teaching strategies in which students are given more chances or options while they are learning and speaking. Multiple intelligences theory based instruction helps in involving and reaching more and more students in the learning process because it addresses various types of intelligences whether these intelligences are scholastic (verbal/linguistic intelligences and the logical/mathematical intelligences) or non-scholastic intelligences ( interpersonal, intrapersonal, and bodily-kinesthetic intelligences, etc.).

It also calls for giving a due care for the speaking skills because of the ultimate importance of these skills in the academic institutions or as a necessity for applying for certain jobs. Furthermore, Prospective teachers of English should develop their speaking skills to be able to develop these skills once they become teachers of English at schools. Mastering speaking skills is very important for those prospective teachers of English because they will 
be involved in situations that require them to be well-trained in such important skills. In addition, the study is also hoped that this study will help them develop teaching courses to meet the needs of the faculty of Education based on the learner-centered approach.

\subsection{Relevant Scholarship}

The ultimate goal of language use is to achieve communicative purposes. Language learners use language functionally in their daily life to different extents. They usually use language to read newspapers, short stories or even books. Also, they frequently use language to write shopping lists, diaries, or even reports. On the other hand, language learners rarely listen to news broadcast in target language or speak with native speakers in English language. Oral communication skills (listening and speaking skills) are viewed as the most difficult to be developed. Researchers explain why language learners are reluctant to develop their speaking skills because they lack native speaking environment as well as the learners' apprehension. Using alternative teaching strategies depending on brain-based instruction as well as addressing various abilities, aptitudes and intelligences may help develop speaking skills (Salem, 2012).

EI-Basel (2008:74) argues that speaking skills have been found a fundamental skill necessary for a person's success in life. Speaking skills cover a wide range, from engaging in simple conversation to formal public speaking.

Speaking is the targetskill in both first and foreign languages. Developing the ability to speak orally to another person is a source of motivation for most learners of foreign languages. Of all the four skills, speaking seems to be the most important, since people who know a language for a long time are said to be "speakers" of that language (EI-Basel, 2008:77).

Speaking skills play a vital role in communication process. It is the most important type from the types of linguistic activities. Developing speaking skill helps in creating an effective connection among the individuals' society. It is an active part in their daily life and a tool of learning (Dorgham, 2011:1).

Similar to the listening skill, speaking skill, according to Sayed (2005:42) is a complicated skill as it involves many processes or operations working together. Speaking involve the linguistic, social, psychological, cultural components. The social aspect of speaking is apparent when we deal with another one who may have a different social or cultural background. According to Al-Khuli (2000:4), speaking requires that learners not only know how to produce specific points of language such as grammar, pronunciation, or vocabulary (linguistic competence), but also they understand when, why, and in what ways to produce language (Sociolinguistic competence).

Ibrahim (2007:1) views that "speaking is a complicated mental process and a productive skill." Also, Brown (2001:9) argues that speaking is not a single skill, rather speaking is an interactive process of constructing meaning that involves producing, receiving and processing information. In addition, Harmer (2001:15) points out that speaking include two categories; accuracy and fluency. This means that developing speaking skill involves the correct use of vocabulary, grammar, pronunciation and having the ability to speak spontaneously.

To be proficient speakers, learners need to acquire the way native speakers use the language inthe contextof structured interpersonal exchange, and to use the language appropriately in social interactions which are an ability that should be mastered to achieve effective oral communication. Social interactions include verbal communication, paralinguistic elements of speech such as pitch, stress, and intonation, and nonlinguisticelements of speech such as gesture, body language posture and facial expression that may accompany speech or convey messages. Therefore, being a fluent speaker entails intensive exposure to the target language. Minimal exposure to the target language and contact with native speakers results inpoor speaker of English especially regarding fluency, and control of idiomatic expressions.

Abdullah (2008:46-47) views that there are various difficulties that face teachers as well as students found in teaching as well as learning speaking in the English language classroom in Egypt. First of all; it is naturally difficult for students to speak in the foreign language they are learning. Second, the teaching conditions that students are involved in can impede the development of their speaking skills. Third, the teachers' methods of teaching can hinder the oral ability of their students. Fourth, students have passive attitudes towards English, particularly in Egypt. They are reluctant to participate in the speaking activities inside the classroom. Fifth, there are psychological factors that may passively influence the students' performances in speaking. Speaking is often viewed as an 'anxiety-provoking' activity.

Consequently, developing the speaking skill entails getting rid of the anxiety provoking atmosphere relating to the speaking experiences. Also, due care should be paid to training learners to speak intensively inside and 
outside the classroom. In addition, more focus to the enrichment of students' vocabulary could help developing speaking ability. We live in an Arabic speaking language environment where English is a foreign language. Meanwhile, we focus on the importance of plunging students in an English speaking environment; students have only minimal exposure to English language. English is practiced only inside the classroom. Therefore, intensive practice of speaking skills is a must.

Providing students with an effective environment enables language speakers to speak fluently and interact freely with each other. This encouraging environment makes learners speak away from anxiety and apprehension. One of these approaches that depend greatly on the learner-centered style of teaching and learning is Howard Gardner's theory of Multiple Intelligences. Multiple intelligences-based instruction helps to reduce the dominance of the teachers for the sake of their learners which broaden the range in front of learners to practice and speak using the target language. According to El Naggar (2000:25), Multiple Intelligences Theory enables teachers to discuss positive strengths in all children and to plan appropriate learning strategies for a more effective classroom environment.

Various studies investigated the effect of using multiple intelligences-based instruction on developing speaking skills). One of these studies was conducted in Upper Egypt by Sayed (2005). It investigated the effect of using a Multiple Intelligences-Based Training Programme on developing first-year English major's oral communication skills. The sample of the study consisted of 30 first year English majors. Tools of the study included: A training programme based on Gardner's MI Theory to develop the students' oral communication skills, and an oral communication pre-posttest that was administered to the group of the study before and after their training. Results revealed that the programme had a great effect on the students' oral communication skills as there are statistically significant differences between the pre and post administration of the test.

Another study was conducted by Dorgham (2011) which investigated the effectiveness of using multiple intelligences based instruction on developing speaking skills of the preparatory schools first graders. The implementation of a program based on MI proved the usefulness of multiple intelligences based instruction on developing first year preparatory stage graders. The current study has different sample but similar general aim.

Ibrahim (2007) investigated the effectiveness of using a suggested strategy based on the multiple intelligences theory on assessing and developing the speaking skills. The sample of the study was third year primary school Arabic native speakers' students. Instruments of the study included the training program (student's book and a teacher's guide), multiple intelligences scale and a checklist of the study showed the usefulness of the training program based on the multiple intelligences theory.

\subsubsection{Limitations of the Study}

The current study is limited to the following:

1. Sixty fourth-year Prospective teachers of English who were willing to participate in the study at Hurgada Faculty of Education, Department of English. Those students were particularly chosen because they need to develop their speaking skills through a program based on multiple intelligences theory as they are going to be teachers of English at the elementary schools (supposedly they will be primary stage teachers of English. Yet, they may work in the intermediate or even secondary schools) the following year.

2. Certain speaking skills that should be developed within the program. These skills are listed as follows:

* Giving oral presentations.

* Making requests.

* Making Suggestions.

* Giving advice.

3. The content of the training programme that deals with at least five types of intelligences: verbal/linguistics, bodily/kinesthetic, interpersonal, Intrapersonal, natural and spiritual intelligences. These intelligences were selected as they are relevant to the content presented in the training program.

\subsubsection{Definition of Terms}

The following definitions were operationally adopted in the study.

\section{Multiple Intelligences-Based Instruction}

Gardner ( 1999:142-144) views Multiple Intelligences-Based Instruction as a tool through which any content area can be conveyed to students by utilizing their different inner capacities, abilities or intelligences. Using this type of instruction addresses many of the students' intelligences as students are involved in various activities 
which are based on different types of intelligences.

\section{Speaking Skills}

Sayed (2005:17) defines speaking as " an interactive process two persons or more are involved in a real-life situation they exchange talk or use the language so as to fulfill a certain communicative purpose or accomplish a certain social function."

Radwan (1999: 9) defines speaking as the oral fluent productive mastery of L2 in different context as one component of the oral communication skills.

The current study defines speaking as " an interactive process that includes certain skills such as giving oral presentation, making suggestions, making requests and giving advices that foster oral fluency of the prospective teachers of English through the use of at least five types of intelligences "

\section{Pre-Service Teachers of English}

Prospective teachers of English are the fourth-year students at the faculties of education including primary stage prospective teachers of English.

\subsection{Hypotheses of the Study}

The researcher used the Quasi-experimental Design to test the hypotheses of the study. This research design is suitable for the nature of the study. Thus the researcher has assigned the experimental group which is pretested and posttested using a test of speaking skills of English majors. The main hypotheses were tested:

There are statistically significant differences between the mean scores of the experimental group in Students' Performance in Speaking Skills and Subskills.

From these main hypotheses, the following hypotheses are derived:

1) There is a statistically significant difference between the mean scores of the subjects of the study on the speaking skills pre-posttest in favor of the posttest.

2) There is a statistically significant difference between the mean scores of the oral presentation skills pre-posttest in favor of the posttest.

3) There is a statistically significant difference between the mean scores of the subjects on making requests skill pre-posttest in favor of the posttest.

4) There is a statistically significant difference between the mean scores of the subjects on making suggestions skill in the speaking pre-posttest in favor of the posttest.

5) There is a statistically significant difference between the mean scores of the subjects on giving advices skill component of the speaking pre-posttest in favor of the posttest.

\subsection{Questions of the Study}

The study attempted to answer the following main question:

What is the effectiveness of a Multiple-Intelligence based program in developing EFL prospective teachers of speaking skills?

From this main question, the following sub-questions are derived:

1) What are the speaking skills required for the fourth-year prospective teachers of English?

2) What is the actual performance of prospective teachers of English in speaking skills?

4) What is the Multiple Intelligences profile of the prospective teachers of English?

5) What are the principles of Multiple-Intelligences based instruction in developing EFL prospective teachers' speaking skills?

6) What is the effect of a Multiple Intelligences based program in developing the speaking skills of the prospective teachers of English?

\section{Method}

The following procedures were followed in developing tools, teaching materials and the procedures followed in administering the tools to the subjects of the study as well as an overall description of how the experiment was conducted. In this way, the experimental aspects of the study were sufficiently covered, and the details of the experiment were clarified. 


\subsection{The Experimental Design}

The current study followed the one-pre-post experimental design in which only the experimental group was used in the implementation process. This design was chosen because the study aims at developing some speaking skills of a group of students and not at comparing two groups. This group was exposed to a speaking pre-posttest and a training program based on Multiple Intelligences Theory to develop the students' speaking skills.

Therefore, the one group pre-posttest design was utilized in the experiment. The study sample was purposefully chosen and assigned to one group from amongst the population of fourth year primary stage prospective teachers of English in Hurgada faculty of Education, South Valley University. The participants are sixty fourth-year prospective teachers of English. The participants studied the new training program after they were pretested. At the end of the experiment, the speaking skills test was administered.

\subsection{Variables of the Study}

\section{The Independent variable was:}

The use of the multiple intelligences-based instruction program

2. The dependent variables were:

Students' speaking skills

3. The control variables were.

a. Age level.

b. Language proficiency level in speaking.

c. Years of studying English.

\subsection{The Participants of the Study}

The participants under investigation were derived from fourth-year prospective teachers of English at Hurgada Faculty of Education, South Valley University. Sixty students were selected according to their willingness to participate in the study.

\subsubsection{Sampling Procedures}

The number of the students who initially desired to participate in the study was (70) students. Ten students did not complete till the end of the training program, therefore, they were not post-tested. The remaining (60) students were involved in one experimental group which was instructed and trained in order to develop their speaking skills in English through a multiple intelligences-based instruction training program.

\subsubsection{Sample Size, Power, and Precision}

The participants were homogenous in terms of their academic level in English in general, and their speaking skills in particular. This was reflected from their scores in their third year university study in general and their scores in the "speaking skills" course in the third year.

\subsubsection{Measures and Covariates}

Students were subjected to the speaking skills test which lasted for two hours and the oral presentation test which lasted for a week of continuous interviews and video recording. This was done before exposing the students to the training program. The oral presentation test was in the form of an interview to determine each one's actual performance level in oral fluency skills before training and to be a basis on which the post-performance would be compared. After the implementation of the program, each student was post tested in the speaking skills included in the program.

The mean of the students' score in the speaking skills test was (18) out of (36). The maximum score in the speaking skills pretest was (26), while the minimum score was (0). The mean scores of the students' oral presentation interview pretest was (15) out of (30). The maximum score was (24), while the minimum score was (0).

\subsubsection{Validating the Tests}

After modifying the test according to the suggestions of the jury members, the tests were conducted in order to:

1. Assure the clarity of the test items and instructions.

2. Decide the time needed for the tests.

3. Determine the item difficulty index of tests. 
4. Determine the discrimination index of the tests.

5. Determine the tests reliability.

To pilot the tests, a number of fifteen students, other than those of an experiment, were randomly selected from among the fourth year prospective teachers of English in Hurgada Faculty of Education.

\subsubsection{Experimental Manipulations and Intervention}

\subsubsection{A Checklist of Students' Speaking Skills}

After reviewing the courses of Hurgada Faculty of Education and going through literature on the speaking skills, a checklist for the TEFL lecturers of the most important speaking skills was suggested. This checklist was submitted to a panel of jury members of specialists in TEFL and linguistics. Members of the jury were asked to:

1. Determine the most important speaking skills that fourth-year primary stage prospective teachers of English need to develop.

2. Modify the linguistic statement of any skill when necessary.

3. Add any other necessary skills students would need to develop.

Table 1. Results of the speaking skills checklist

\begin{tabular}{llll}
\hline Speaking Skills & Agreement & Percentage \\
\hline 1 & Giving Oral Presentations & 10 & $100 \%$ \\
2 & Making Suggestions & 8 & $80 \%$ \\
3 & Making Requests & 9 & $90 \%$ \\
4 & Making Advices & 8 & $80 \%$ \\
\hline
\end{tabular}

\subsubsection{Multiple Intelligences Inventory for EFL Young Adults}

A Multiple Intelligences Inventory for EFL Young Adults developed by McKenzie (1999) was administered to the experimental group of the prospective teachers of English. Through this inventory, the students were given some feedback so as to be aware of their preferred intelligences. It also gave the researcher a profile of students' preferred intelligences. Based on this basis, the researcher designs the activities and tasks in accordance with the students' preferred intelligences.

Table 2. Profile of the most dominant intelligences of the participants

\begin{tabular}{llll}
\hline \multicolumn{2}{l}{ Types of Intelligences } & Mean & $\begin{array}{l}\text { Standard } \\
\text { Deviation }\end{array}$ \\
\hline 1 & Interpersonal Intelligence & 16.17 & 1.467 \\
2 & Verbal-Linguistic Intelligences & 15.533 & 2.318 \\
3 & Intrapersonal Intelligence & 15.167 & 1.993 \\
4 & Logical-Mathematical Intelligence & 13.350 & 1.764 \\
5 & Bodily/kinesthetic Intelligence & 13.967 & 0.938 \\
\hline
\end{tabular}

\subsubsection{The Speaking Pre-Posttest}

\section{a. Aim of the test}

The test was used to develop giving oral presentations, making requests, making suggestions and giving advice in the pre and post testing.

b. Description of the test

The test was divided into four parts as follows:

Part (1) Giving oral presentations.

Part (2) Making requests. 
Part (3) Making Suggestions.

Part (4) Giving advice.

The total score of the written part of the test was 36 points, whereas the oral presentation was 30 points according to the scoring rubric.

These parts represented the core of unit three of the program. Designing the test was based on reviewing pertinent viewpoints of EFL specialists and reviewing related literature.

Table 3. Table of specification of the speaking pre-posttest

\begin{tabular}{lllll}
\hline Speaking Skills & $\begin{array}{l}\text { Number } \\
\text { Items }\end{array}$ & $\begin{array}{l}\text { of } \\
\text { Marks }\end{array}$ & $\begin{array}{l}\text { Total } \\
\text { Mean }\end{array}$ \\
\hline 1 & Giving Oral Presentations & 1 & 30 & $83.33 \%$ \\
2 & Making Suggestions & 1 & 12 & $33.33 \%$ \\
3 & Making Requests & 1 & 12 & $33.33 \%$ \\
4 & Making Advices & 1 & 12 & $33.33 \%$ \\
\hline
\end{tabular}

c. Validity of the Speaking Skills Pre-post Test

The test was submitted to a jury to decide on:

1. Clarity of test instructions.

2. Suitability of test items for assessing the speaking skills of the fourth year primary stage prospective teachers of English students.

3. Suitability of test items for the fourth year primary stage prospective teachers of English students' level.

4. Suitability of the proposed scoring technique.

5. Any other comments or suggestions.

Some modifications were made in the wording of the test instructions in the light of the jury members' comments especially in those who have a psychological background.

The jury members decided that the test is generally valid to be used in assessing the fourth year primary stage prospective teachers of English's speaking and oral presentation skills.

d. Reliability of the test

The researcher used the inter-rater reliability to determine the reliability of the test. Two raters participated in scoring the speaking skills and oral presentation skills by students participating in the speaking skills pre-posttest (each rater was given a separate copy of the test papers to score by himself) after they were instructed in scoring tests using the scoring criteria. Scores given by the two raters were correlated using Pearson Formula. The correlation coefficient between the first and second rater is 0.911 at significance level 0.01 .

\section{Results}

Results of implementing the program were tallied and tabulated to decide on the effect of the multiple intelligences-based instruction approach on the fourth year prospective teachers of English performance in speaking skills test.

\subsection{Statistical Procedures}

The Statistical Package for Social Sciences (SPSS, version 17.0) was used in the treatment of the results of the study. T-test formula was employed in analyzing students' scores on the speaking skills test.

\subsection{Validating the Study Hypotheses}

In order to validate the study hypotheses, the researcher tabulated data obtained from participants' raw scores. After tabulating these data to cope with the statistical formulas, the researcher used the Statistical Package for Social Sciences (SPSS) version 17 to make the necessary statistics. The researcher made the simple descriptive statistics to calculate means of scores and standard deviation. The researcher then calculated the observed t-test in order to compare means of scores and subsequently to determine the accurate effect of the proposed program. In order to make sure that the statistical differences between the mean scores are due only to the training 
program and nothing else, the researcher calculated the effect size.

\subsection{The Main Research Hypothesis}

The Main hypothesis of the study was stated as follows:

There is a statistically significant difference between the mean scores of the subjects of the study on the speaking skills pre-posttest in favor of the posttest.

Table 4 sets outs the results of analyzing students' scores on the speaking skills test.

Table 4. T-test results of students' scores on the speaking skills test

\begin{tabular}{cccccc}
\hline Subjects & $\begin{array}{c}\text { Number of } \\
\text { students }\end{array}$ & $\begin{array}{c}\text { Mean } \\
\text { score }\end{array}$ & $\begin{array}{c}\text { Standard } \\
\text { deviation }\end{array}$ & $\begin{array}{c}\text { Observed } \\
t \text {-value }\end{array}$ & $\begin{array}{c}\text { The Effect } \\
\text { Size }\end{array}$ \\
\hline Pretest & 60 & 20.72 & 7.921 & $14.705^{*}$ & 0.753 \\
Posttest & 60 & 34.18 & 2.514 & & \\
\hline
\end{tabular}

$* \mathrm{P} \leq .001$

It is clear from the data represented in table 4 that there is a statistically significant difference between mean scores of the subjects' pre-posttest scores on the speaking skills test. This difference is in favor of the post testing. This indicates that the new program was beneficial to the subjects of the study concerning the speaking component. Therefore, the hypothesis is accepted, i.e. there is a statistically significant difference between mean scores of the subjects of the study in the pretest and posttest on the speaking skills test in favor of the posttest. This result coincides with the study conducted by Dorgham (2011), Sayed (2005) and Ghazala (2005). All of these studies reveal that using MI based instruction is effective in developing speaking skills.

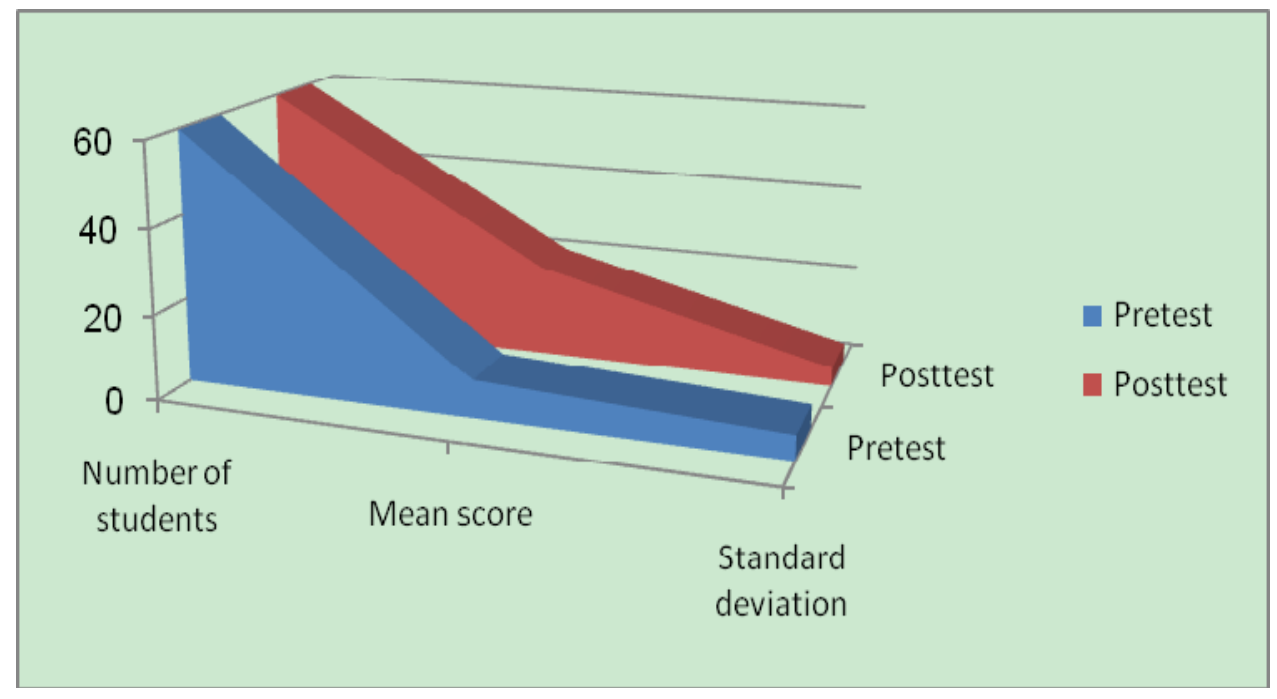

Figure 1. T-test results of students' scores on the speaking skills test

\subsection{The First Research Hypothesis}

The first hypothesis of the study was stated as follows:

There is a statistically significant difference between the mean scores of the oral presentation skills pre-posttest in favor of the posttest.

Table 5 sets outs the results of analyzing students' scores on the oral presentation skills test. 
Table 5. T-test results of students' scores on the oral presentation skills test

\begin{tabular}{cccccc}
\hline Subjects & $\begin{array}{c}\text { Number of } \\
\text { students }\end{array}$ & Mean score & $\begin{array}{c}\text { Standard } \\
\text { deviation }\end{array}$ & $\begin{array}{c}\text { Observed } \\
t \text {-value }\end{array}$ & $\begin{array}{c}\text { The Effect } \\
\text { Size }\end{array}$ \\
\hline Pretest & 60 & 8.77 & 5.673 & $18.009^{*}$ & 0.782 \\
Posttest & 60 & 21.63 & 4.491 & & \\
\hline
\end{tabular}

$* \mathrm{P} \leq .00 \overline{1}$

It is clear from the data represented in table 5 that there is a statistically significant difference between mean scores of the subjects of the study in the pretest and posttest on the oral presentation skills component. This difference is in favor of the post test scores. This indicates that the new program was beneficial to the subjects concerning the oral presentation skills. Therefore, the hypothesis is accepted, i.e. there is a statistically significant difference between mean scores of the subjects in the pretest and posttest on the oral presentation skills in favor of the posttest.

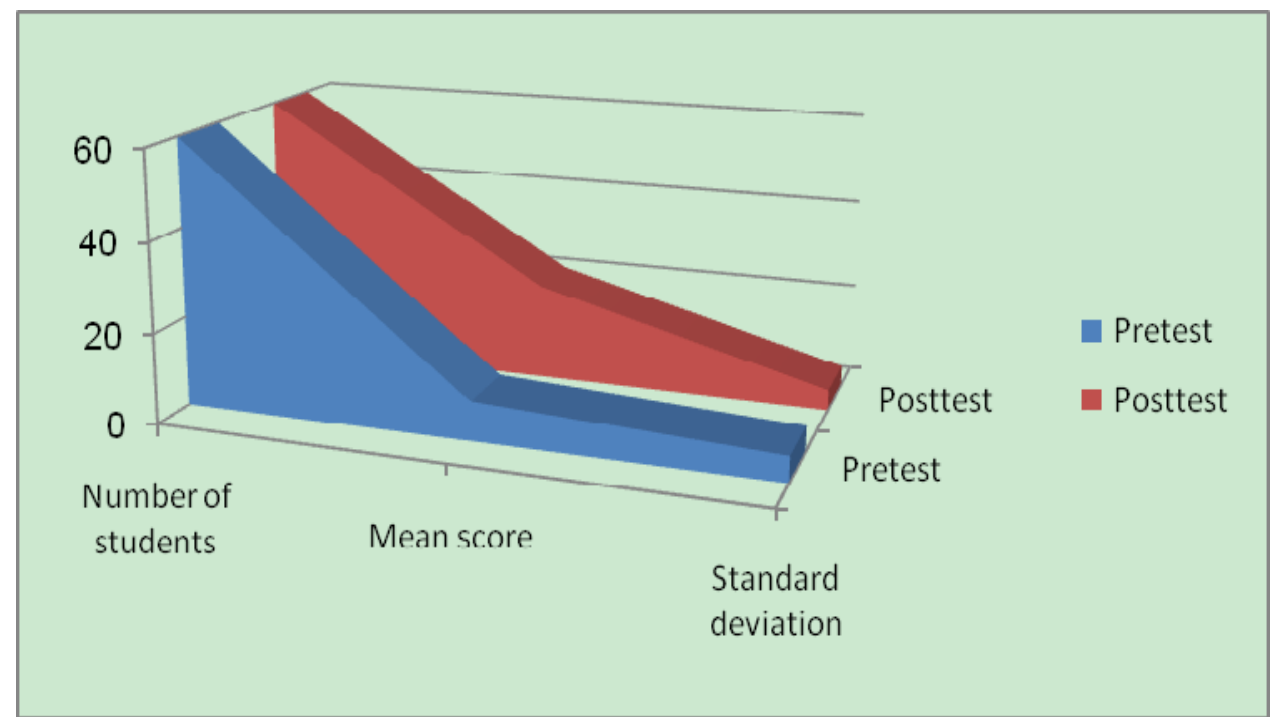

Figure 2. T-test results of students' scores on the oral presentation skills test

\subsection{The Second Research Hypothesis}

The second hypothesis of the study was stated as follows:

There is a statistically significant difference between the mean scores of the subjects on making requests skill pre-posttest in favor of the posttest.

Table 6 sets out the results of analyzing students' scores on the making requests pre-posttest

Table 6. T-test results of students' scores on the making requests component of the speaking pre-posttest

\begin{tabular}{cccccc}
\hline Subjects & $\begin{array}{c}\text { Number of } \\
\text { students }\end{array}$ & $\begin{array}{c}\text { Mean } \\
\text { score }\end{array}$ & $\begin{array}{c}\text { Standard } \\
\text { deviation }\end{array}$ & $\begin{array}{c}\text { Observed } \\
t \text {-value }\end{array}$ & $\begin{array}{c}\text { The Effect } \\
\text { Size }\end{array}$ \\
\hline Pretest & 60 & 10.20 & 3.150 & $3.874^{*}$ & 0.310 \\
Posttest & 60 & 11.68 & 0.596 & & \\
\hline
\end{tabular}

$* \mathrm{P} \leq .001$

Data represented in table 6 reveals that there is a statistically significant difference between mean scores of the subjects of the study on the pre and posttest on the making requests component of the speaking pre-posttest favoring the post testing. This indicates that the subjects benefited from the new program concerning this 
component. Therefore, the hypothesis is accepted, i.e. there is a statistically significant difference between mean scores of the subjects in the making requests skill in pre-posttest in favor of the post test. This result is similar to that of Sayed (2005) concerning the effectiveness of using MI based instruction on developing oral presentation skills of the first year prospective teachers of English.

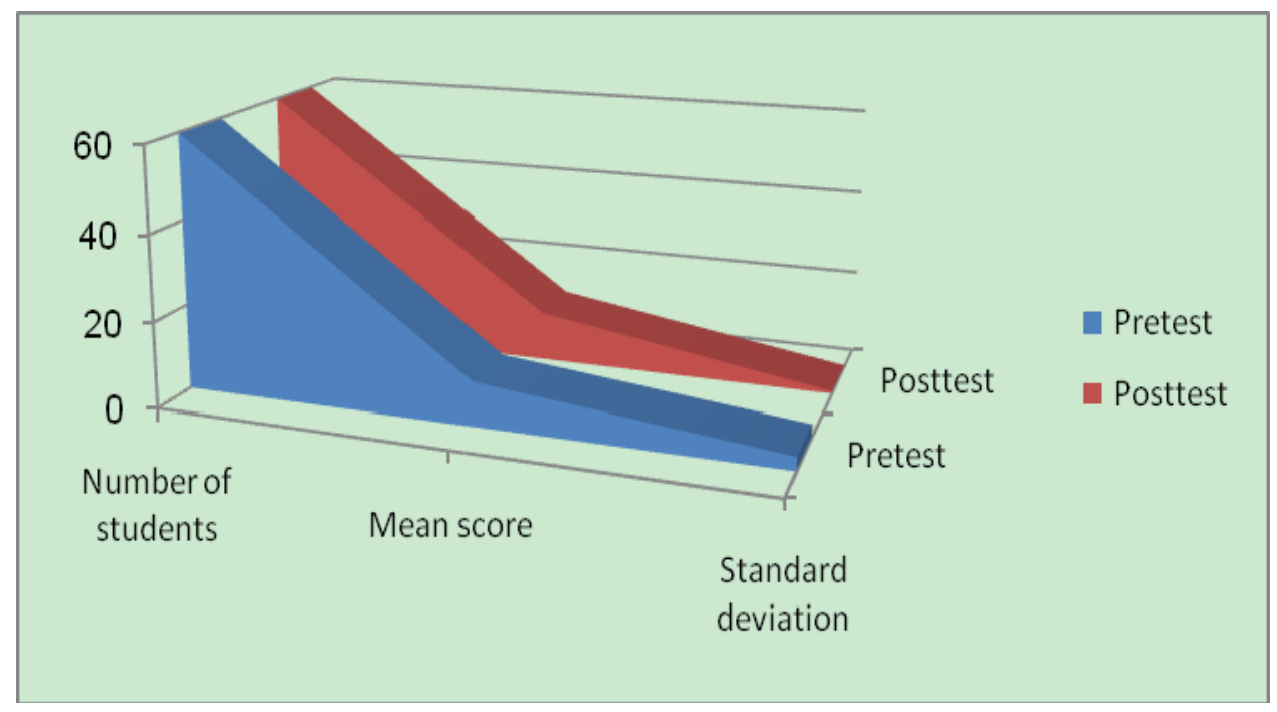

Figure 3. T-test results of students' scores on the making requests component of the speaking pre-posttest

\subsection{The Third Research Hypothesis}

The third hypothesis of the study was stated as follows:

There is a statistically significant difference between the mean scores of the subjects on making suggestions skill in the speaking pre-posttest in favor of the posttest.

Table 7 sets out the results of analyzing students' scores on the making suggestions component in the speaking pre-posttest.

Table 7. T-test results of students' scores on the making suggestions component of the speaking pre-posttest

\begin{tabular}{cccccc}
\hline Subjects & $\begin{array}{c}\text { Number of } \\
\text { students }\end{array}$ & $\begin{array}{c}\text { Mean } \\
\text { score }\end{array}$ & $\begin{array}{c}\text { Standard } \\
\text { deviation }\end{array}$ & $\begin{array}{c}\text { Observed } \\
t \text {-value }\end{array}$ & $\begin{array}{c}\text { The Effect } \\
\text { Size }\end{array}$ \\
\hline Pretest & 60 & 8.48 & 3.481 & $6.808^{*}$ & 0.516 \\
Posttest & 60 & 11.50 & 0.624 & & \\
\hline
\end{tabular}

$* \mathrm{P} \leq .001$

Data represented in table 7 reveals that there is a statistically significant difference between mean scores of the subjects of the study on the pre and posttest on the making suggestions component of the speaking pre-posttest favoring the post testing. This indicates that the subjects benefited from the new program concerning this component. Therefore, the hypothesis is accepted, i.e. there is a statistically significant difference between mean scores of the subjects in the making suggestions skill in pre-posttest in favor of the post test. 


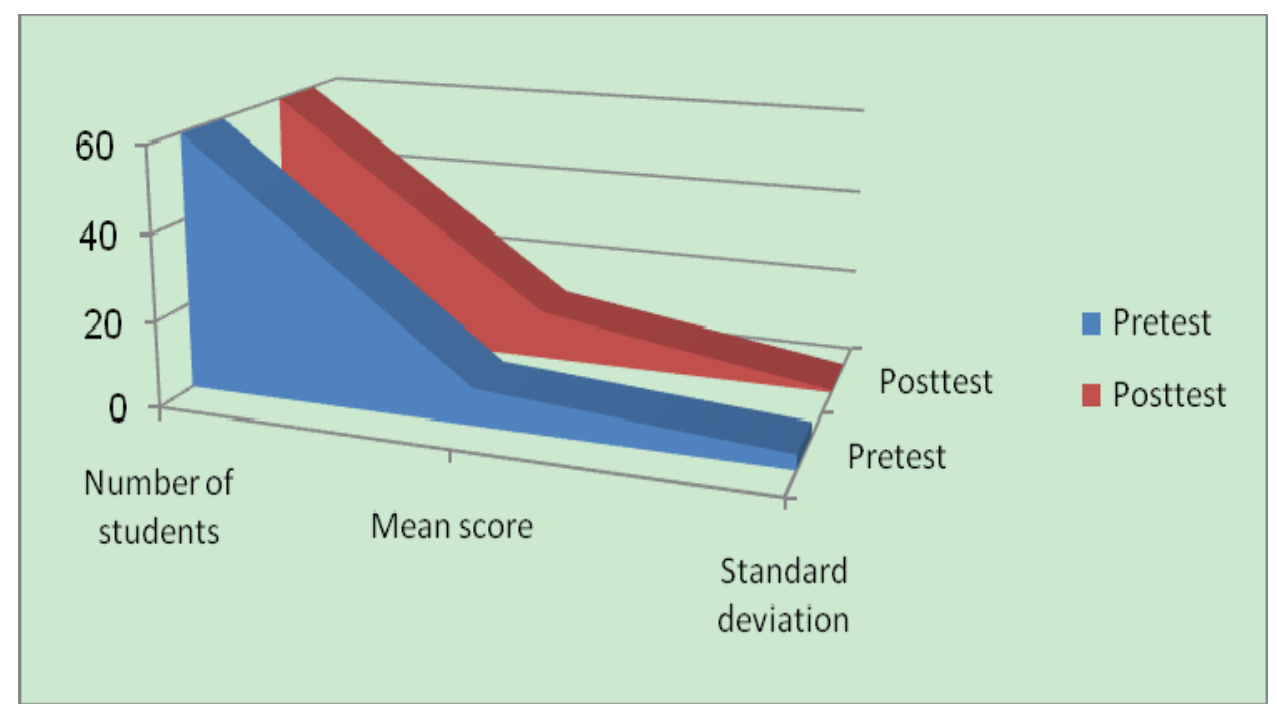

Figure 4. T-test results of students' scores on the making suggestions component of the speaking pre-posttest

\subsection{The Fourth Research Hypothesis}

The fourth hypothesis of the study was stated as follows:

There is a statistically significant difference between the mean scores of the subjects on giving advices skill component of the speaking pre-posttest in favor of the posttest.

Table 8 sets out the results of analyzing students' scores on the giving advice component of the speaking pre-posttest

Table 8. T-test results of students' scores on the giving advices component of the speaking pre-posttest

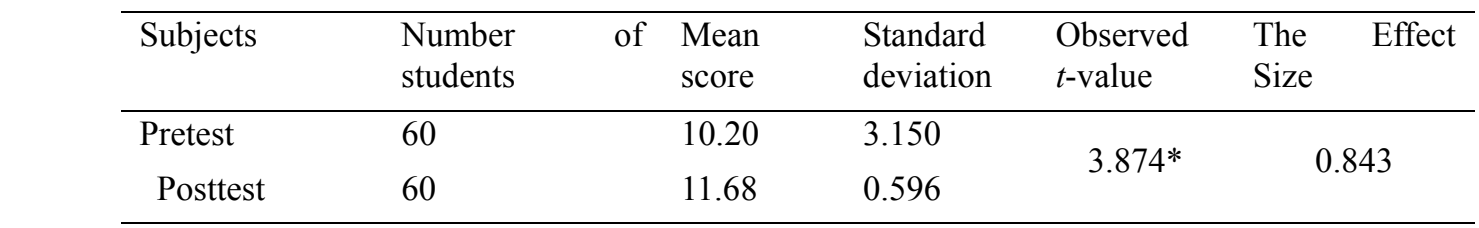

$* \mathrm{P} \leq .001$

Data represented in table 8 reveals that there is a statistically significant difference between mean scores of the subjects of the study on the pre and posttest on the giving advices component of the speaking pre-posttest favoring the post testing. This indicates that the subjects benefited from the new program concerning this component. Therefore, the hypothesis is accepted, i.e. there is a statistically significant difference between mean scores of the subjects in the giving advices skill in the speaking pre-posttest in favor of the post test. 


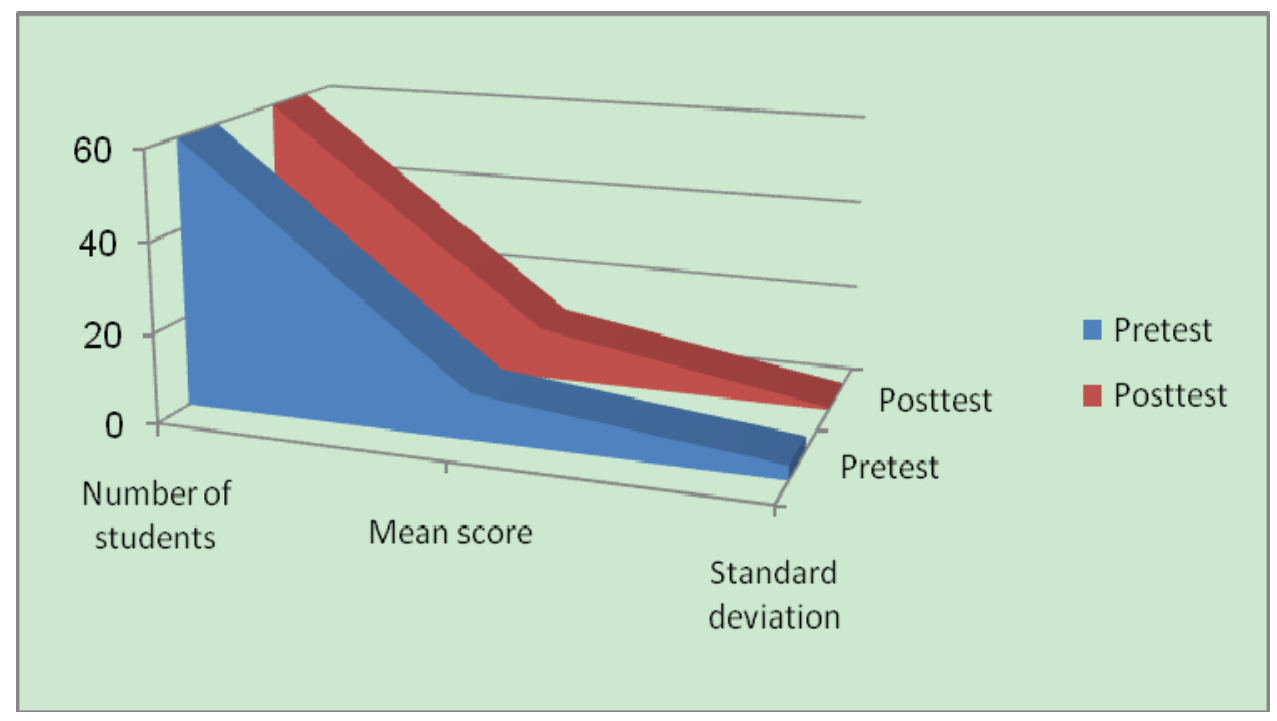

Figure 5. T-test results of students' scores on the giving advices component of the speaking pre-posttest

\section{Discussion}

The main aim of the current study was to investigate the effectiveness of using a program that depends on the theory of multiple intelligences in developing the speaking skills of the fourth year prospective teachers of English at Hurgada faculty of Education, South Valley University.

The results of the study showed that there is a statistically significant difference at the significance level $(0.01)$ between the mean scores of the participants on the speaking pre-posttest in favor of the posttest. This might be attributed to the activities and tasks of the program that improvement in students' performance of the speaking skills (namely, giving oral presentation, making requests, making suggestions, and giving advice).

Consequently, the results of the current study concur with many studies which used MI Theory" in developing and improving many academic skills in the field of teaching foreign language in general (Condis, et al., 2000; Geimer, et al., 2000), and in the field of English Language Teaching in particular ", in the field of speaking (Dorgham, 2011 \& Sayed, 2005).

This result copes with Sayed's study (2005) which investigated the effect of using a Multiple Intelligences-Based Training Programme on developing first-year English majors' oral communication skills. The sample of the study consisted of thirty first-year English majors. Results revealed that the programme had a great effect on the students' oral communication skills.

Students demonstrated significant improvement in the oral presentation skills. This improvement can be attributed to the program as well. The participants were given information about the different techniques that a good presenter uses. Effective opening of speech, using visuals and commenting on these visual as well as using sounds effectively. These techniques helped students be effective presenters. Also, they helped them in other speaking skills such as giving advice, expressing requests and expressing suggestions. Providing the students with information about these patterns of order was not yet sufficient to attribute this improvement to the new program. This information was followed by many chances for real application and experimentation. This, of course, was done through the multiple and varied activities contained in the program. Thus, the systematic training in oral presentation skills included throughout the program was a rich experience for the participants to receive drill practice in this area.

The third component handled in this hypothesis is the speaking skills. The participants manifested significant gains in speaking skills. These gains can be attributed to the activities of the new program. Because of the importance of speaking in general, the researcher paid due focus to this area. For example, the participants were instructed in using language functions, as speaking skills. Furthermore, the Student's Workbook was provided with a supplementary material that included the most important speaking students were likely to need in different daily situations. Therefore, the improvement taking place in the speaking skills can be attributed to the effectiveness of the program. 


\section{Conclusions}

Based on the results of the study it can be concluded that using multiple intelligences based instruction is an effective way to develop the speaking skills through focusing on individual differences among students. It is also concluded that coping the new trends in teaching which focuses on the changing role of the teacher from being a lecturer to a facilitator enhances students' achievement.

\section{Acknowledgements}

All thanks goes to Dr Ahmed Abdulsalam Idrees, TEFL lecturer, Zagazig University. Also, my gratitude for Dr. Azza Marsfy, professor of TEFL, Zagazig University. A big thank you for Dr. Ali Madkour, Professor of Arabic Language Teaching, Cairo University. Due thanks goes to Dr. Elham Abdulhameed, professor of Curricula and Instruction, Cairo University. The biggest thank you goes to Dr. Mahmoud Al-Naka, Professor of Arabic Language Teaching, Ain Shams University. All thanks goes to Dr Mahmoud Sayed, TEFL lecturer, Assuit University for his help and guidance. Many thanks go to my dear colleagues in the State of Kuwait. Many thanks go to my father, mother, wife, my daughters Malak, Nour and my son Yousif.

\section{References}

Abdullah, M. M. S. (2008). Multiple Ways to be Smart: Gardner's Theory of Multiple Intelligences and its Educational English Teaching and Oral Communication. Retrieved from http://www.ericedu.org.eg

Brown, H. D. (2001). Teaching by principles: An interactive approach to learning pedagogy. White Plains, NY: Longman.

Condis, P., Parks, D., \& Soldwedel, R. (2000). Enhancing vocabulary and Language using Multiple Intelligences. Master of Arts Action Research Project, Saint Xavier University and Skylight Professional Development. Retrieved from http://www.ericedu.gov.eg.doi.441269Cs 510325

Dorgham, R. A. S. (2011). The effectiveness of a proposed program in developing the speaking skills of English language among preparatory stage pupils in the light of multiple intelligences theory. Unpublished $\mathrm{PhD}$ thesis. Institute of Educational Studies. Cairo University.

El Naggar, Z. (2000). Learners' individual differences. In El Naggar, Z., Fadel, R., McClosky, M., \& Thoronton, B. (Eds). SPEER (Spotlight on Primary English Education Resources): A resource text for Egyptian primary English educators, supervisors and teachers. Academy for educational Development.

El-Basel, R. M. (2008). The Effectiveness of Multimedia Program Using Animation to Develop the Speaking Skill in English for the Pupils of the Primary Stage (pp. 82-85). MA Thesis, Cairo University, Institute of Educational Studies.

Gardner, H. (1999). Frames of Mind: The Theory of Multiple Intelligences (10th Ed.). New York basic Rooks.

Geimer, M., Jennifer, P., \& Terry, P. K. (2000). Improving Student Achievement in Language Arts through Implementation of Multiple Intelligences strategies. Master of Arts Action Research Project, Saint Xavier University and Skylight Professional Development. http://www.ericedu.gov.eg.doi.444 185 CS 217242

Ghazala, Sh. A. (2005) The Effectiveness of a Suggested Programmae Based on the Theory of Multiple Intelligences on Developing Second Year Primary School Pupils' Listening and Speaking Skills. Journal of Faculty of Education, Azhar University, 127(3), 1-15.

Harmer, J. (2001). The Practice of English Language Teaching. Longman: Longman Press.

Ibrahim, A. H. A. (2007). The Effectiveness of a Suggested Teaching Strategy Based on Multiple Intelligences Theory on Developing Third Year Primary School Pupils' Speaking Skills. Unpublished MA Thesis. Institute of Educational Studies. Cairo University.

Radwan, S. S. (1999). The Effectiveness of Using Cooperative Learning for Developing the Communicative Oral Skill of First Year Students in the Department of English at Port-Said Faculty of Education. Suez Canal University.

Salem, A. A. M. (2012). The Effect of Multiple Intelligences Theory Based on Instruction on Developing Listening and Speaking Skills of Prospective Teachers of English. Unpublished PhD in Teaching English as a foreign language. Institute of Educational Studies. Cairo University.

Sayed, M. M. (2005). The effect of using a multiple intelligences-based training programme on developing English majors' oral communication skills. Unpublished MA Thesis. Faculty of Education. Assuit University. 


\section{Copyrights}

Copyright for this article is retained by the author(s), with first publication rights granted to the journal.

This is an open-access article distributed under the terms and conditions of the Creative Commons Attribution license (http://creativecommons.org/licenses/by/3.0/). 